\title{
The Advantages and Disadvantages Analysis on the Online Appraisal System of Independent College
}

\author{
Huan Ji \\ Jincheng College \\ Nanjing University of Aeronautics and Astronautics \\ Nanjing, Jiangsu, China 211156
}

\begin{abstract}
Establishing the effective teaching quality assurance system and perfecting quality guarantee mechanism have important meaning to improve the teaching quality of independent colleges and achieve the goal of cultivating highquality applied talents. It is an important measure that vigorously prompts the online teaching evaluation work during the teaching management process in the independent college for comprehensively understanding the students' suggestion to the teacher's teaching method, strengthening the management of teaching quality $\&$ prompting the teaching quality. Therefore, it is particularly important and urgent that to formulate the scientific and reasonable students' evaluation index system suit to the independent college. This essay takes the online assessment index system of the independent college as the analysis object, and analyzes the advantages and disadvantages of it during the operation process and tries to provide the reference for the building online evaluation system of independent college.
\end{abstract}

Keywords-independent college; online teaching evaluation; advantage and disadvantage

\section{INTRODUCTION}

In order to improve the national education level and overall quality, promote economic and social development, China's higher education obtained the leap-forward development. In the course of higher education development, if the independent college - as the outcome of higher education popularization wants to gain a firm foothold in the increasingly fierce competition among colleges and universities, be accepted by the society, it is necessary for it to improve the quality of personnel, the conditions for running schools \& the efficiency and quality of education, and continuously win a good social reputation to promote the sustainable and healthy development of the school. Therefore, as one important part of higher education in our country, the independent college should pay attention to its living and developing conditions and assurance that strengthen its teaching work and improve the quality of applied talent, which is the base for it. The teaching level of teachers in the independent college plays a key role in completing the teaching quality, which will directly influence the quality of applied talents; therefore, to strengthen the teaching ability is an important part in improving the teaching quality of independent college. It is one of the important effective measures that vigorously implement the online teaching evaluation work to strengthen the teaching quality management, comprehensively understand the suggestions and feedback to the classroom teaching, prompt the teaching perfection and increase the teaching quality.

\section{ANALYSIS ON THE ADVANTAGES AND DISADVANTAGES TO THE ONLINE TEACHING EVALUATION SYSTEM OF INDEPENDENT COLLEGE}

Assess the teacher's work at a certain time via the online teaching evaluation system in the daily teaching process can effectively reflect the teaching quality of the teachers, which also can guide the teachers to orderly carry out their work according to the weight percentage. In the concrete implementation, the exam to classroom teaching segment has been paid much attention in the evaluation index system, thus, it has become an important duty to how to improve the teaching skills and methods, how to increase the acceptance of the student to the class teaching. Meanwhile, the online teaching evaluation also has been taken as a base for HR to check the teaching quality and KPI at yearly end.

\section{A. Main Index for the Online Teaching Evaluation System of Independent College}

First, teaching attitude, which includes five 2 class index the teachers should be neat and generous, full of energy; abide by the teaching discipline; come to work on time and do not leave early; approachable, caring students; rigorous scholarship, strict requirements for students; - carefully guidance, consultant, Q\&A, check homework. Second, teaching content, which includes five 2nd class index teaching content of each unit; the teachers should pay attention to choose and enrich the teaching content; the lecture content is logical and good at summing up; correctly narrate the basic concept \& principle; Pay attention to combining the teaching contents to carry on the ideological and political education. Third, teaching method, which includes that using the heuristic method for teaching; skillfully adopt the teaching method(PPT, projection and multimedia, can make beautiful courseware; adopt the standard, clear, simple and interesting word; be good at adjust the class atmosphere; be good at taking advantage of examples, figures and pictures to explain the abstract concept and principle. Fourth, emotion and value, which includes -five 2 class index - the good relationship between the teachers and students, good communication between them; take care the study of the students, help the students with difficulties; the influence caused by the dedication and sense of responsibility 
of the teachers to the students; prompt the study interest of the students by the teachers' teaching; improve the confidence and set ambitious target of the students by the teachers' teaching. Fifth, teaching result, which includes four 2 class index - the student can better understand, absorb and master the key \& important points of the textbook; the thinking of the students keeps the same steps with the teaching; extend the knowledge scope, prompt the comprehensive quality via this class, the teacher fully take advantage of the class time.

\section{B. Advantages of the Online Teaching Evaluation Index System of Independent College}

The online teaching evaluation index system of the independent college conforms to the macro environment of setting up school at that time, and helps to roughly evaluate the teachers' teaching quality at a certain degree, and guides the teacher orderly run his teaching activity via setting the index system, which are mainly reflected via the following two aspects:

1) Guide the young teachers to pay much attention to the classroom teaching via setting the content of the index system: For example, in a certain time, check the application effect of the teaching tools such as the blackboard-writing and multimedia etc., organize the contest on PPT and teaching-plan among each departments, which effectively improve the applying ability of the teachers to the teaching methods; exam the interaction ability in class to guide the young teacher to ask questions, explain examples and improve the sense of humor and methods like this to increase the interaction between the teachers and students, which effectively improve the application ability of teaching methods.

2) Guide the teachers to clarify the priority in the teaching process and regulate their teaching behavior via setting the weight of index system: As the independent college, the independent college has the features that most of the teachers are young and most of them are the postgraduate students who just graduated from university, whose teaching concepts and methods are similar, such as they have teaching passion and good attitude, but are not good at teaching methods and skills and especially lack of ability in controlling the class; in the practice of young teachers, due to lack of participation of teachers, the teaching direction will goes to the wrong point, that is there are too much passion which is not good for improving the real teaching effect, at this time, it is necessary to have an guiding evaluation index to guide the young teacher to find the right teaching direction. In the past online teaching evaluation index, there is a higher weight on the teaching methods and skills, which is bound to guide the young teachers to reasonably carry out the teaching activity so as to indirectly help them to improve the teaching level and skills.

Comprehensively, at the special background of "newborn country" at the beginning of school, the online evaluation index system of the independent college did has the mentioned parts needed to be improved, but it cann't be ignored that, at the current times, this system do help the independent college to carry out a series of teaching evaluation to teachers, and the researched theme covered by this essay is also improved on this base.

\section{Advantages of the Online Teaching Evaluation Index System of Independent College}

Though the online teaching index system of the independent college has some advantages at a certain time and space, with the bound of the macro environment of school, it also has some kinds of disadvantages, which especially exists in perfecting the detail of teaching evaluation, checking the teaching practice, setting the weight of the index with subjective color and so on, which should be changed immediately to adapt the development requirement of social economy, the change of educational teaching conditions and concepts, or the changeless teaching evaluation system will put off the improvement of the teaching level and effect.

As known, independent college is a public private secondary college, at the beginning of school, the teaching management style and talent training model are set up according to its maternal teaching management style and talent training model. At that time, the teaching evaluation model of the independent college was still in the dualistic structure was influenced by the maternal college and tried to find its own feature, thus, the online teaching evaluation index system of it was in a status that self-image was not clear, which were mainly reflect via the following 3 aspects:

1) The content of the index system is too general and the refinement is not high: The index system only simply list some indexes that reflect the teaching project, but do not systematically summarize the content, so it can not reflect the difference and levels between the primary and secondary index.

2) The index system focuses too much on the classroom steps, but does not clearly reflect the evaluation of practical aspects and teaching effectiveness: The evaluation of the details of classroom teaching such as the blackboard-writing, the appearance, the lecture and so on can make a certain evaluation to the teachers 'classroom mastery, but the lack of practice and effect evaluation such as students' practical ability, knowledge understanding and application ability will be disadvantageous to the comprehensive evaluation of a teacher's teaching level.

3) The weight of the index system is subjective: In the early stage of running the independent college, the scale of the students is in rapid development, the teaching task is arduous, and the corresponding teaching management mechanism is not perfect. In this situation, the weight of the evaluation system is not measured by quantitative means, but measured by the subjective determination of the teaching management personnel, so the rationality of the weight of index should be improved.

4) It does not reflect the evaluation of practical teaching links, is not conducive for the development of the independent colleges-take train high-quality application-oriented talents as its objective: The reform direction of the Ministry of Education is clear: there will be more than 600 colleges and universities of the national 1200 schools will be transferred as the vocational education, accounting for just $50 \%$ of the total number of colleges and universities. According to the media, China's higher education personnel training structure will undergo significant changes, the proportion of colleges and 
universities developing technical and technical talents will increase from the existing $55 \%$ to $70 \%-80 \%$. "In the modern society, the purpose of society is not only the pursuit of academic, with the market orientation, people increasingly give priority to the operational, computable and useful knowledge in the labor market." Therefore, applied education is attracting people's more and more attention. In order to adapt to the national education reform and development, the independent college takes the regional development and industry development as the guide, strengthens the practice of teaching links, and takes train high-quality applied talents as the goal. But the past evaluation system did not reflect the development of the new situation, which led to the slogan of teaching objectives and teaching evaluation-oriented run different track, is not conducive to the realization of the established school concept "study at school and practice the personal ability, work at society and use the knowledge in actual situation ".

5) The scores of teaching evaluation are relatively high, the gap is small, which can not reflect the teachers' actual teaching level: Through the continuous analysis of the scores of four semesters, it is found that almost $90 \%$ of the teachers' scores are more than 90 points, almost no difference. It cannot truly and effectively reflect the teaching situation of teachers. For the teacher with relatively low teaching level did not play a certain spur role. On the contrary for the ones with relatively high teaching level did not play an incentive role. There is a big difference between the results of this evaluation and the actual teaching situation, which cannot reasonably reflect the teacher's actual teaching level, and greatly reducing the role of online teaching evaluation.

\section{CONCLUSION}

Practice has proved that in the evaluation of teacher teaching, students' evaluation is more practical and reliable than peer's evaluation and teachers' self-evaluation. In foreign countries, the results of students 'evaluation of teaching are not only fed back to teachers, but also widely used in the evaluation of school level, professional assessment, curriculum evaluation, teachers' teaching evaluation, teachers' promotion, teachers' lecture $\&$ hiring and selection activities $\&$ procedures of the excellent teaching awards and so on. In China, the results of students' evaluation are not directly used for teachers' appointment, promotion and salary determination, but because there are no other indicators to measure teachers' teaching, the results of students' evaluation are often used indirectly for teachers' decision-making by HR. Many colleges and universities have been brought the evaluation of teaching students into the teaching quality monitoring system, and become as an important part of teaching quality assurance system.

With the speeding up of information construction, at present, there is a kind of teaching quality management and monitoring means, which is commonly used in higher education institutions in China -online teaching evaluation. During the teaching management process of the independent college, it is an important measure to comprehensively understand the students' opinions and reflections on the teachers' teaching via the online teaching evaluation so as to promote the improvement of the teachers' teaching and the teaching quality of the independent quality.

\section{REFERENCES}

[1] Sha Wu, Chong Li. A Comparative Study on the Index System of Student Evaluation in China and the United States $[\mathrm{J}]$. 职大学报, 2013,(3):114-116.

[2] Xiaorui Chen. The Theory and Practice of the Teaching Evaluation by Students in American Universities $[\mathrm{J}]$. Comparative Education Research,2001,(2):29-32

[3] Xinguang Shi. An Analysis to the Problems and Countermeasures of Students' Teaching Evaluation in Independent Colleges [J]. Educational Education Forum.2014,(39):136-137.

[4] Yushan Liu. An Analysis of the Differences in the Index System of Students' Evaluation of Higher Education in China and Canada [J] .Fudan Education Forum.2014.12(2):41-60

[5] Yongkai Zhou, Hongyan Tian, Wenbo Wang. Modern University Teaching Evaluation Theory and Practice [M]. Beijing: China Light Industry Press, 2010

[6] Yanping Zhou, Huiying Chen, Aiping Jiang, Ruiying Zhao. Analysis on the Influencing Factors of Plant Variety Right in Seed Enterprises Based on the Questionnaire Survey of Seed Enterprises in 14 Provinces and Cities [J] .China Science and Technology Forum,2012(5):144.

[7] Dong Du, Qinghua Pang. Modern Comprehensive Evaluation Methods and Case Selection [M]. Beijing: Tsinghua University Press,2005.

[8] Tao Dong. A Comprehensive Evaluation of Power Grid Planning Project [D]; Baoding: Journal of North China Electric Power University;2008.

[9] Wenhui Chen. Post-evaluation of Project [M]. Beijing: China Economic Publishing House, 2009.

[10] Aiting Xu. The Application and Difficulties of Delphi Method [J] .China Statistics, 2006, (9): 57-59. 